Vol 2 No 2 Desember 2021

Jurnal AlphaEuclidEdu

Received: 08/09/2021; Resived: 13/10/2021; Accepted: 30/12/2021

\title{
ANALISIS KONSEP MATEMATIKA SEKOLAH DALAM PEMULASARAAN JENAZAH
}

\author{
Tsamara Banafsaj ${ }^{1}$, Ahmad Yani $\mathbf{T}^{2}$, Asep Nursangaji ${ }^{3}$ \\ Program Studi Pendidikan Matematika, FKIP, Universitas Tanjungpura, Pontianak \\ Email: tsamaraasa@gmail.com
}

\begin{abstract}
This research aim to identify the elementary and junior high school mathematic concepts which included the funeral procession. The process of funeral procession that was researched included measuring and cutting the shroud, bathing the corpse, shrouding the corpse, praying the corpse, and burying the corpse. The method of this research is a qualitative, and the form of this research is a literature study. Then the data were collected using documents in the form of books, articles, and notes on the results of the funeral procession by the fardhu kifayah team of Ummu Al-Athiyyah Al-Anshoriyyah. Based on the Miles and Huberman analysis method, elementary and junior high school mathematical concepts are found in the funeral procession, namely rectangles, mixed arithmetic operations, addition, subtraction, multiplication, division, number sequences, sets, linear inequalities of one variable, line segments, vertical lines, horizontal lines, parallel lines, perpendicular lines, point outside the line, 180 degree angel, and cuboids.
\end{abstract}

Keywords: Concept, School Mathematics, Funeral Procession

\section{Pendahuluan}

Matematika sekolah memiliki keterkaitan dengan setiap aktivitas di dalam kehidupan manusia. Karena, salah satu tujuan dari pembelajaran matematika sekolah itu sendiri adalah untuk mempersiapkan siswa agar dapat menggunakan matematika dan pola pikir matematika dalam kehidupan sehari-hari dan dalam berbagai ilmu pengetahuan (Soedjadi, 2000: 43). Pada kenyataannya, keterkaitan matematika sekolah dengan kehidupan manusia tidak hanya terbatas pada hal-hal dunia saja, namun juga dalam hal agama. Dari hasil penelitian Transyah (2018) terungkap bahwa dalam ibadah shalat, ada konsep-konsep matematika yang terkait, antara lain: penjumlahan bilangan cacah, perkalian bilangan cacah, kelipatan dua, himpunan, barisan aritmatika, ruas garis, konsep garis sejajar, dan sudut. Hasil penelitian Puspitasari (2017) terungkap bahwa di dalam sistem hukum waris Islam masyarakat Semudun juga terdapat konsep matematika sekolah yang terkait, yaitu: himpunan, bilangan bulat, operasi penjumlahan bilangan bulat, operasi pengurangan bilangan bulat, operasi perkalian bilangan bulat, operasi pembagian bilangan bulat, operasi pengurangan bilangan pecahan, dan operasi perkalian bilangan pecahan. Termasuk dalam hal agama adalah tentang pemulasaraan jenazah. Banyak orang yang tidak mengetahui bahwa pemulasaraan jenazah juga memiliki keterkaitan dengan konsep matematika sekolah.

Berdasarkan hasil wawancara prariset dengan satu di antara anggota Tim Fardhu Kifayah Ummu Al-Athiyyah Al-Anshoriyyah pada 6 Juli 2020, didapat informasi bahwa terdapat banyak keterkaitan antara matematika sekolah dengan pengurusan (pemulasaraan) jenazah. Sebab dari proses awal ada proses pengukuran, membagi bahan sesuai ukuran yang diperlukan, menggunakan alat ukur panjang secara manual seperti jengkal, memperkirakan berapa lama waktu menjahit kain kafan, mengkafani, dan 
Vol 2 No 2 Desember 2021

Jurnal AlphaEuclidEdu

Received: 08/09/2021; Resived: 13/10/2021; Accepted: 30/12/2021

memandikan agar selesai tepat waktu, dan pada saat memandikan penyiraman air kapur barus harus di angka ganjil terakhir.

Pemulasaraan Jenazah adalah rangkaian prosedur yang harus dilakukan seorang Muslim yang masih hidup yang sudah memenuhi ketentuan untuk melaksanakannya dalam rangka menunaikan hak jenazah. Rangkaian prosedur tersebut secara umum mencakup memandikan, mengafani, mensholatkan, dan memakamkan jenazah. Selain setiap diri diperintahkan untuk mempersiapkan diri dalam menghadapi kematian, juga diperintahkan untuk bisa memulasarakan jenazah sebagai bentuk pemenuhan hak jenazah orang lain. Karena, setiap manusia yang hidup di dunia pasti akan merasakan kematian. Sebagaimana dalam firman Allah, "Segala sesuatu pasti binasa, kecuali Allah." (Q.S. Al-Qashash : 88). Sehingga, tidak menutup kemungkinan bahwa nantinya siswa Muslim akan melaksanakan pemulasaraan jenazah.

Hukum memulasarakan jenazah adalah fardhu kifayah. Artinya, wajib bagi sebagian Muslim untuk mempelajari dan mempraktikkannya, dan jika tidak ada satupun orang dalam suatu kelompok yang mempelajari dan mempraktikkannya maka dapat dikenai dosa. Adanya keterkaitan antara matematika sekolah dengan pemulasaraan jenazah berdasarkan hasil wawancara di atas, menunjukkan bahwa di dalam pemulasaraan jenazah dapat dianalisis lebih lanjut mengenai apa saja konsep matematika sekolah yang terdapat di dalamnya. Sehingga, hasil analisis tersebut dapat dimanfaatkan sebagai contoh kontekstual dalam mengajarkan suatu konsep matematika di sekolah, khususnya sekolah Islam. Dengan mengetahui adanya konsep matematika sekolah tersebut, diharapkan pula dapat mempermudah siswa dalam melaksanakan pemulasaraan jenazah. Berdasarkan penjelasan di atas, peneliti tertarik untuk mengkaji penelitian terkait "Analisis Konsep Matematika Sekolah Dalam Pemulasaraan Jenazah".

\section{Metode Penelitian}

Metode penelitian yang digunakan dalam penelitian ini adalah penelitian kualitatif. Denzin dan Lincoln (dalam Umar Sidiq, 2019) mengemukakan bahwa penelitian kualitatif merupakan penelitian yang menggunakan latar belakang alamiah, dengan maksud menafsirkan fenomena yang terjadi dan dilakukan dengan jalan melibatkan berbagai metode yang ada dalam penelitian kualitatif. Metode yang biasanya dimanfaatkan adalah wawancara, pengamatan, dan pemanfaatan dokumen.

Adapun tujuan penelitian ini adalah untuk mengidentifikasi konsep matematika sekolah dalam pemulasaraan jenazah. Maka bentuk penelitian yang digunakan adalah studi literatur atau penelitian kepustakaan. Menurut Zed (dalam Eka Diah Kartiningrum, 2015), Studi literatur adalah serangkaian kegiatan yang berkenaan dengan metode pengumpulan data pustaka, membaca dan mencatat, serta mengolah bahan penelitian.

Sumber data dalam penelitian ini yaitu Buku Fiqih Jenazah Menurut Al-Qur'an dan As-Sunnah oleh Muhammad Nashiruddin Al-Albani, Buku Shalat Fiqih 4 Madzhab oleh Abdurrahman Al-Jaziri, Buku Kitab Ahkamul Janaiz oleh Abu Fadhli Rabbani, dan catatan hasil pelatihan pemulasaraan jenazah oleh Tim Fardhu Kifayah Al-Athiyyah AlAnshoriyyah, dan beberapa dokumen lainnya yang berkaitan dengan penelitian.

Prosedur penelitian dalam penelitian ini yaitu:

\section{Tahap Persiapan}

Tahap persiapan dalam penelitian ini antara lain (1) Membuat daftar dan mendeskripsikan tata cara memulasarakan jenazah; (2) Membuat daftar dan 
Vol 2 No 2 Desember 2021

Jurnal AlphaEuclidEdu

Received: 08/09/2021; Resived: 13/10/2021; Accepted: 30/12/2021

mendeskripsikan materi matematika sekolah SD/MI dan SMP/MTs; (3) Menyusun desain penelitian; (4) Membuat pedoman dan tabel pengamatan; (5) Seminar desain penelitian.

\section{Tahap Pelaksanaan}

Tahap pelaksanaan dalam penelitian ini berupa (1) Menganalisis konsep matematika sekolah yang terdapat dalam pemulasaraan jenazah; (2) Mengklasifikasikan konsep tersebut berdasarkan ruang lingkup materi; (3) Menyesuaikan konsep yang ditemukan dengan jenjang pendidikan siswa.

\section{Tahap Akhir}

Tahap akhir dalam penelitian ini yaitu (1) Menyusun hasil dan pembahasan berdasarkan hasil analisis data; (2) Membuat kesimpulan dan saran; (3) Menyusun laporan.

\section{Hasil Penelitian dan Pembahsan \\ Hasil Penelitian}

Berdasarkan hasil analisis peneliti, diperoleh data berupa rangkaian dalam pemulasaraan jenazah yang terdapat konsep matematika sekolah di dalamnya, yang secara ringkas dapat dilihat pada beberapa tabel berikut.

Tabel 1. Hasil Penelitian Konsep Matematika Sekolah Dalam Rangkaian Proses Mengukur dan Memotong Kain Kafan

\begin{tabular}{|c|c|c|c|}
\hline No & Kontekstual & Pokok Materi & Konsep Matematika Sekolah \\
\hline 1 & Bentuk Kain Kafan & $\begin{array}{l}\text { Geometri dan } \\
\text { Pengukuran }\end{array}$ & Persegi Panjang \\
\hline 2 & $\begin{array}{c}\text { Pembagian Kain } \\
\text { Kafan }\end{array}$ & Bilangan & $\begin{array}{l}\text { Operasi Hitung Campuran } \\
\text { Bilangan Cacah dan Desimal }\end{array}$ \\
\hline 3 & $\begin{array}{c}\text { Pembuatan Kain } \\
\text { Dasar }\end{array}$ & Bilangan & $\begin{array}{c}\text { Operasi Penjumlahan } \\
\text { Operasi Pengurangan } \\
\text { Operasi Perkalian } \\
\text { Operasi Pembagian } \\
\text { Operasi Hitung Campuran }\end{array}$ \\
\hline 4 & Pembuatan 7 utas tali & Bilangan & $\begin{array}{l}\text { Operasi Pembagian } \\
\text { Operasi Penjumlahan }\end{array}$ \\
\hline
\end{tabular}

Berdasarkan tabel 1, konsep matematika sekolah yang terdapat dalam rangkaian mengukur dan memotong kain kafan yaitu pada pokok materi Bilangan dan Geometri. Dalam pokok materi Bilangan, konsep matematika sekolah yang terkandung yaitu: (1) Operasi Hitung campuran; (2) Operasi penjumlahan; (3) Operasi Pengurangan; (4) Operasi Perkalian; dan (5) Operasi Pembagian. Sedangkan dalam pokok materi Geometri terdapat konsep persegi panjang.

Tabel 2. Hasil Penelitian Konsep Matematika Sekolah Dalam Rangkaian Proses Memandikan Jenazah

\begin{tabular}{|l|c|c|c|}
\hline No & Kontekstual & Pokok Materi & Konsep Matematika Sekolah \\
\hline
\end{tabular}


Vol 2 No 2 Desember 2021

Jurnal AlphaEuclidEdu

Received: 08/09/2021; Resived: 13/10/2021; Accepted: 30/12/2021

\begin{tabular}{|c|l|c|c|}
\hline $\mathbf{1}$ & $\begin{array}{l}\text { Banyaknya proses } \\
\text { memandikan jenazah }\end{array}$ & Bilangan & Barisan Bilangan \\
\hline $\mathbf{2}$ & $\begin{array}{l}\text { Banyaknya proses } \\
\text { memandikan jenazah } \\
\text { dengan air larutan sabun } \\
\text { atau daun bidara }\end{array}$ & Bilangan & Barisan Aritmatika \\
\hline $\mathbf{3}$ & $\begin{array}{l}\text { Waktu untuk memandikan } \\
\text { jenazah dengan air larutan } \\
\text { kamper }\end{array}$ & Bilangan & Barisan Bilangan \\
\hline
\end{tabular}

Berdasarkan tabel 2, konsep matematika sekolah yang terdapat dalam rangkaian memandikan jenazah yaitu terdapat pada pokok materi Bilangan saja, dengan konsep matematika barisan bilangan dan barisan aritmatika.

Tabel 3. Hasil Penelitian Konsep Matematika Sekolah Dalam Rangkaian Proses Mengafani Jenazah

\begin{tabular}{|c|c|c|c|}
\hline No & Kontekstual & Pokok Materi & Konsep Matematika Sekolah \\
\hline 1 & $\begin{array}{lr}\text { Banyaknya lapisan } \\
\text { kain kafan } \\
\text { jenazah }\end{array}$ & Bilangan & Operasi Penjumlahan \\
\hline
\end{tabular}

Berdasarkan tabel 3, konsep matematika sekolah yang terdapat dalam rangkaian mengafani jenazah yaitu pada pokok materi Bilangan, dengan konsep operasi penjumlahan.

Tabel 4. Hasil Penelitian Konsep Matematika Sekolah Dalam Rangkaian Proses Menshalatkan Jenazah

\begin{tabular}{|c|l|c|ll|}
\hline No & \multicolumn{1}{|c|}{ Kontekstual } & Pokok Materi & \multicolumn{1}{|l|}{ Konsep Matematika Sekolah } \\
\hline $\mathbf{1}$ & $\begin{array}{l}\text { Jumlah minimal dan } \\
\text { maksimal jama'ah } \\
\text { shalat jenazah }\end{array}$ & Aljabar & $\begin{array}{l}\text { Himpunan } \\
\text { Pertidaksamaan Linear Satu } \\
\text { Variabel }\end{array}$ \\
\hline $\mathbf{2}$ & $\begin{array}{l}\text { Jumlah barisan jama'ah } \\
\text { shalat jenazah }\end{array}$ & Aljabar & $\begin{array}{l}\text { Himpunan } \\
\text { Pertidaksamaan Linear Satu } \\
\text { Variabel }\end{array}$ \\
\hline $\mathbf{3}$ & $\begin{array}{l}\text { Posisi barisan shalat } \\
\text { jenazah }\end{array}$ & $\begin{array}{l}\text { Geometri dan } \\
\text { Pengukuran }\end{array}$ & $\begin{array}{l}\text { Ruas Garis } \\
\text { Garis Sejajar }\end{array}$ \\
\hline $\mathbf{4}$ & $\begin{array}{l}\text { Jumlah takbir dalam } \\
\text { shalat jenazah }\end{array}$ & Bilangan & Operasi Perkalian \\
\hline $\mathbf{5}$ & $\begin{array}{l}\text { Posisi berdiri imam } \\
\text { terhadap jenazah laki- } \\
\text { laki dan perempuan }\end{array}$ & $\begin{array}{l}\text { Geometri dan } \\
\text { Pengukuran }\end{array}$ & Titik di Luar Garis \\
\hline $\mathbf{6}$ & $\begin{array}{l}\text { Posisi berdiri seseorang } \\
\text { dalam shalat jenazah } \\
\text { terhadap jenazah }\end{array}$ & $\begin{array}{l}\text { Geometridan } \\
\text { Pengukuran }\end{array}$ & $\begin{array}{l}\text { Ruas Garis } \\
\text { Garis Vertikal } \\
\text { Garis Horizontal } \\
\text { Garis Tegak Lurus }\end{array}$ \\
\hline
\end{tabular}


Vol 2 No 2 Desember 2021

Jurnal AlphaEuclidEdu

Received: 08/09/2021; Resived: 13/10/2021; Accepted: 30/12/2021

\begin{tabular}{|l|l|l|}
\hline & & Sudut $180^{\circ}$ \\
\hline
\end{tabular}

Berdasarkan tabel 4, konsep matematika sekolah yang terdapat dalam rangkaian menshalatkan jenazah yaitu terdapat pada pokok materi Bilangan, Aljabar dan Geometri. Dalam pokok materi Bilangan, konsep matematika sekolah yang terkandung yaitu operasi perkalian. Kemudian dalam pokok materi Aljabar, terdapat konsep: (1) Himpunan dan (2) Pertidaksamaan linear satu variabel. Sedangkan dalam pokok materi Geometri terdapat konsep: (1) Ruas Garis; (2) Garis sejajar; (3) Titik di luar garis; (4) Garis tegak lurus; (5) Garis Vertikal; (6) Garis Horizontal; dan (7) Sudut $180^{\circ}$.

Tabel 5. Hasil Penelitian Konsep Matematika Sekolah Dalam Rangkaian Proses Memakamkan Jenazah

\begin{tabular}{|c|c|c|c|}
\hline No & Kontekstual & Pokok Materi & Konsep Matematika Sekolah \\
\hline $\mathbf{1}$ & Bentuk lubang kubur & $\begin{array}{c}\text { Geometri dan } \\
\text { Pengukuran }\end{array}$ & Balok \\
\hline
\end{tabular}

Berdasarkan tabel 5, konsep matematika sekolah yang terdapat dalam rangkaian memakamkan jenazah yaitu terdapat pada pokok materi Geometri saja, dengan konsep matematika balok.

\section{Pembahasan \\ Mengukur dan Memotong Kain Kafan \\ Bentuk Kain Kafan}

Kain kafan yang digunakan adalah kain yang memiliki bentuk menyerupai bangun datar persegi panjang ketika dihamparkan. Kain tersebut memiliki ciri-ciri yang sangat mendekati ciri-ciri bangun datar persegi panjang, yaitu memiliki dua pasang sisi yang masing-masing sama panjang dan sejajar dengan pasangannya. Selain itu, kain kafan memiliki ciri yang sama dengan persegi panjang dalam hal sudut, yaitu keempat sudutnya berbentuk siku-siku karena sisi panjang dan sisi lebarnya saling berpotongan tegak lurus. Pada pembahasan ini, sisi panjang kain adalah sisi yang bersesuaian dengan tinggi badan jenazah, dan sisi lebar kain adalah sisi yang bersesuaian dengan lebar badan jenazah.

\section{Pembagian Kain Kafan}

Pada pembagian kain kafan, terkandung operasi hitung campuran. Operasi hitung campuran yang dimaksud adalah operasi perkalian bilangan cacah dan penjumlahan bilangan cacah dan desimal. Konsep-konsep ini saling berhubungan satu sama lain.

Konsep operasi penjumlahan terdapat pada panjang setiap pola yang jika dijumlahkan akan setara dengan panjang kain utuh. Namun, satuan panjang pola yang disajikan tidak semuanya sama. Padahal, panjang setiap pola dapat dijumlahkan jika satuannya sama. Panjang pola ada yang dinyatakan dalam satuan meter dan ada pula yang dinyatakan dalam satuan sentimeter, sedangkan panjang kain kafan utuh dinyatakan dalam satuan meter. Oleh karena itu, untuk dapat menjumlahkan panjang setiap pola, maka satuan panjang masing-masing pola dikonversi terlebih dahulu ke dalam meter, yang kemudian disesuaikan dengan panjang kain utuh dalam satuan meter.

Dalam tangga satuan panjang, untuk mengonversi suatu satuan panjang ke suatu satuan panjang lain yang tingkatnya lebih bawah, maka setiap satu kali melangkah ke 
Vol 2 No 2 Desember 2021

Jurnal AlphaEuclidEdu

Received: 08/09/2021; Resived: 13/10/2021; Accepted: 30/12/2021

bawah, ia dikalikan dengan 10. Sedangkan untuk mengonversi suatu satuan panjang ke suatu satuan panjang lainnya yang tingkatnya lebih atas ia dibagi dengan 10 . Untuk mengonversi sentimeter ke meter memerlukan dua kali naik tangga. Maka, $1 \mathrm{~cm}=((1$ : 10) : 10) $\mathrm{m}=0.01 \mathrm{~m}$.

Pada proses pembagian kain kafan, kain dipotong pada sisi panjang kain atau pola pemotongannya sejajar dengan sisi lebar kain. Misal panjang kain utuh adalah x meter dan panjang masing-masing polanya adalah a meter yang dibuat sebanyak 5 lembar, $\mathrm{b}$ meter, dan $\mathrm{c}$ meter. Maka, $\mathrm{x}$ meter $=5 \times$ a meter $+\mathrm{b}$ meter $+\mathrm{c}$ meter. Perhitungan ini mengandung konsep operasi perkalian dan penjumlahan. Sebuah perkalian bilangan $a \times b$ diartikan sebagai penjumlahan bilangan $b$ sebanyak a kali.

Jadi, $a \times b=b+\underbrace{b+b+\ldots+b}$

Sebanyak a kali

Konsep hubungan antar satuan panjang serta operasi hitung campuran pada pembagian kain kafan disajikan dalam tabel berikut ini.

Tabel 6. Konsep Operasi Hitung Campuran Bilangan Cacah dan Desimal

\begin{tabular}{|c|c|c|c|}
\hline No & Panjang Kain Utuh & $\begin{array}{c}\text { Panjang Pola Setelah } \\
\text { Dikonversi }\end{array}$ & $\begin{array}{c}\text { Operasi Hitung } \\
\text { Campuran Bilangan } \\
\text { Cacah dan Desimal }\end{array}$ \\
\hline \multirow[t]{3}{*}{1} & $\begin{array}{ll}\text { Kain kafan } & \text { untuk } \\
\text { jenazah laki-laki } & \end{array}$ & & \\
\hline & $\begin{array}{l}\text { Kain bahan Mori } \\
\text { panjang } 13 \mathrm{~m}\end{array}$ & $\begin{array}{l}\text { Bahan kain dasar } 2.5 \\
\text { m sebanyak } 5 \text { lembar, } \\
\text { cawat } 0.5 \mathrm{~m}\end{array}$ & $\begin{array}{l}5 \times 2.5+0.5=(2.5+2.5+ \\
2.5+2.5+2.5)+0.5=12.5 \\
+0.5=13\end{array}$ \\
\hline & $\begin{array}{l}\text { Kain bahan Drill panjang } \\
7.5 \mathrm{~m}\end{array}$ & $\begin{array}{l}\text { Bahan kain dasar } 2.5 \\
\text { m sebanyak } 3 \text { lembar }\end{array}$ & $\begin{array}{l}3 \times 2.5=2.5+2.5+2.5= \\
7.5\end{array}$ \\
\hline \multirow[t]{4}{*}{2} & $\begin{array}{l}\text { Kain kafan untuk } \\
\text { jenazah perempuan }\end{array}$ & & \\
\hline & $\begin{array}{l}\text { Kain bahan Mori } \\
\text { panjang } 13 \mathrm{~m}\end{array}$ & $\begin{array}{l}\text { Bahan kain dasar } 2.5 \\
\text { m sebanyak } 3 \text { lembar, } \\
\text { jilbab } 0.9 \mathrm{~m} \text {, sarung } \\
1.5 \mathrm{~m} \text {, jubah } 2.5 \mathrm{~m} \text {, } \\
\text { cawat } 0.6 \mathrm{~m}\end{array}$ & $\begin{array}{l}3 \times 2.5+0.9+1.5+2.5+ \\
0.6=(2.5+2.5+2.5)+0.9 \\
+1.5+2.5+0.6=7.5+0.9 \\
+1.5+2.5+0.6=13\end{array}$ \\
\hline & $\begin{array}{l}\text { Kain kafan bahan Mori } \\
\text { panjang } 15 \mathrm{~m}\end{array}$ & $\begin{array}{l}\text { Bahan kain dasar } 2.5 \\
\text { m sebanyak } 4 \text { lembar, } \\
\text { jilbab } 0.9 \mathrm{~m} \text {, sarung } \\
1.5 \mathrm{~m} \text {, jubah } 2 \mathrm{~m} \text {, } \\
\text { cawat } 0.6 \mathrm{~m}\end{array}$ & $\begin{array}{l}4 \times 2.5+0.9+1.5+2+0.6 \\
=(2.5+2.5+2.5+2.5)+ \\
0.9+1.5+2+0.6=10+ \\
0.9+1.5+2+0.6=15\end{array}$ \\
\hline & $\begin{array}{l}\text { Kain kafan bahan Mori } \\
\text { panjang } 16 \mathrm{~m}\end{array}$ & $\begin{array}{l}\text { Bahan kain dasar } 2.5 \\
\text { m sebanyak } 4 \text { lembar, } \\
\text { jilbab } 0.9 \mathrm{~m} \text {, sarung } \\
1.5 \mathrm{~m} \text {, jubah } 2.5 \mathrm{~m} \text {, } \\
\text { cawat } 0.6 \mathrm{~m} \text {, waslap }\end{array}$ & $\begin{array}{l}4 \times 2.5+0.9+1.5+2.5+ \\
0.6+0.5=(2.5+2.5+2.5 \\
+2.5)+0.9+1.5+2.5+ \\
0.6+0.5=10+0.9+1.5+ \\
2+0.6+0.5=16\end{array}$ \\
\hline
\end{tabular}


Vol 2 No 2 Desember 2021

Jurnal AlphaEuclidEdu

Received: 08/09/2021; Resived: 13/10/2021; Accepted: 30/12/2021

\begin{tabular}{|c|c|c|}
\hline & $0.5 \mathrm{~cm}$ & \\
\hline $\begin{array}{l}\text { Kain kafan bahan Drill } \\
\text { panjang } 10 \mathrm{~m}\end{array}$ & $\begin{array}{l}\text { Bahan kain dasar } 2.5 \\
\text { m sebanyak } 2 \text { lembar, } \\
\text { jilbab } 1.5 \mathrm{~m} \text {, sarung } \\
1.5 \mathrm{~m} \text {, jubah } 2 \mathrm{~m} .\end{array}$ & $\begin{array}{l}2 \times 2.5+1.5+1.5+2= \\
(2.5+2.5)+1.5+1.5+2= \\
5+1.5+1.5+2=10\end{array}$ \\
\hline
\end{tabular}

\section{Pembuatan Kain Dasar}

Pada rangkaian ini, terkandung konsep operasi pembagian, operasi penjumlahan, operasi pengurangan, dan operasi hitung campuran. Konsepnya terdapat pada cara pembuatan kain dasar dari bahan yang disiapkan sehingga sisi lebar dari kain dapat cukup menutupi lebar tubuh jenazah. Sedangkan pada sisi panjang dari kain tidak dilakukan pemotongan. Adapun kebutuhan kain dasar jenazah yaitu laki-laki 3 lembar dan perempuan 2 lembar, sehingga hasil akhir dari setiap bahan kain dasar yang dipotong dan dijahit adalah terbentuk 3 lembar kain dasar untuk jenazah laki-laki, dan 2 lembar kain dasar untuk jenazah perempuan. Pembahasannya adalah sebagaimana dalam tabel berikut.

Tabel 7. Konsep Matematika Sekolah Dalam Pembuatan Kain Dasar

\begin{tabular}{|c|c|c|c|}
\hline No & $\begin{array}{l}\text { Jenis dan } \\
\text { Ukuran } \\
\text { Kain Kafan }\end{array}$ & Langkah-langkah & $\begin{array}{c}\text { Konsep } \\
\text { Matematika } \\
\text { Sekolah }\end{array}$ \\
\hline & $\begin{array}{l}\text { Kain kafan untuk } \\
\text { jenazah laki-laki }\end{array}$ & & \\
\hline \multirow[t]{4}{*}{1} & \multirow[t]{4}{*}{$\begin{array}{l}\text { Bahan } \quad \text { Mori } \\
\text { ukuran } 13 \mathrm{~m} \times 90 \\
\mathrm{~cm}\end{array}$} & $\begin{array}{l}\text { Lembar-1 bahan kain dasar dibagi } \\
\text { menjadi } 2 \text { bagian sama besar, dengan } \\
\text { arah pemotongan sejajar sisi panjang. } \\
\text { Artinya, sisi lebar dibagi } 2 \text {. }\end{array}$ & $90 \mathrm{~cm}: 2=45 \mathrm{~cm}$ \\
\hline & & $\begin{array}{l}\text { Hasil potongan tersebut masing- } \\
\text { masing disatukan dengan lembar-2 } \\
\text { dan } 3 \text { bahan kain dasar, dengan cara } \\
\text { dipertemukan sisi-sisi lebarnya. } \\
\text { Artinya, sisi lebar bertambah. }\end{array}$ & $\begin{array}{l}90 \mathrm{~cm}+45 \mathrm{~cm}= \\
135 \mathrm{~cm}\end{array}$ \\
\hline & & $\begin{array}{l}\text { Lembar-4 dan } 5 \text { masing-masing } \\
\text { dipotong selebar } 2 \text { kali } 3 \text { jari tangan } \\
\text { untuk dibuat menjadi tali, dengan } \\
\text { arah pemotongan sejajar dengan sisi } \\
\text { panjang. Lebar } 3 \text { jari tangan } \\
\text { dianggap } 5 \mathrm{~cm} \text {. Artinya, sisi lebar } \\
\text { kain berkurang. }\end{array}$ & $\begin{array}{l}90 \mathrm{~cm}-(2 \times 5 \mathrm{~cm})= \\
90 \mathrm{~cm}-(5 \mathrm{~cm}+5 \\
\mathrm{cm})=90 \mathrm{~cm}-10 \\
\mathrm{~cm}=80 \mathrm{~cm}\end{array}$ \\
\hline & & $\begin{array}{l}\text { Hasil potongan tersebut disatukan, } \\
\text { dengan cara dipertemukan sisi-sisi } \\
\text { lebarnya. Artinya, sisi lebar } \\
\text { bertambah. }\end{array}$ & $\begin{array}{l}80 \mathrm{~cm}+80 \mathrm{~cm}= \\
160 \mathrm{~cm}\end{array}$ \\
\hline 2 & 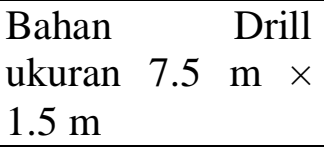 & $\begin{array}{l}\text { Lembar-1 dipotong selebar } 2 \text { kali } 3 \\
\text { jari tangan untuk dibuat menjadi tali, } \\
\text { dengan arah pemotongan sejajar }\end{array}$ & $\begin{array}{l}1.5 \mathrm{~m}-(2 \times 5 \mathrm{~cm})= \\
1.5 \mathrm{~m}-(5 \mathrm{~cm}+5 \\
\mathrm{cm})=1.5 \mathrm{~m}-10 \mathrm{~cm}\end{array}$ \\
\hline
\end{tabular}


Vol 2 No 2 Desember 2021

Jurnal AlphaEuclidEdu

Received: 08/09/2021; Resived: 13/10/2021; Accepted: 30/12/2021

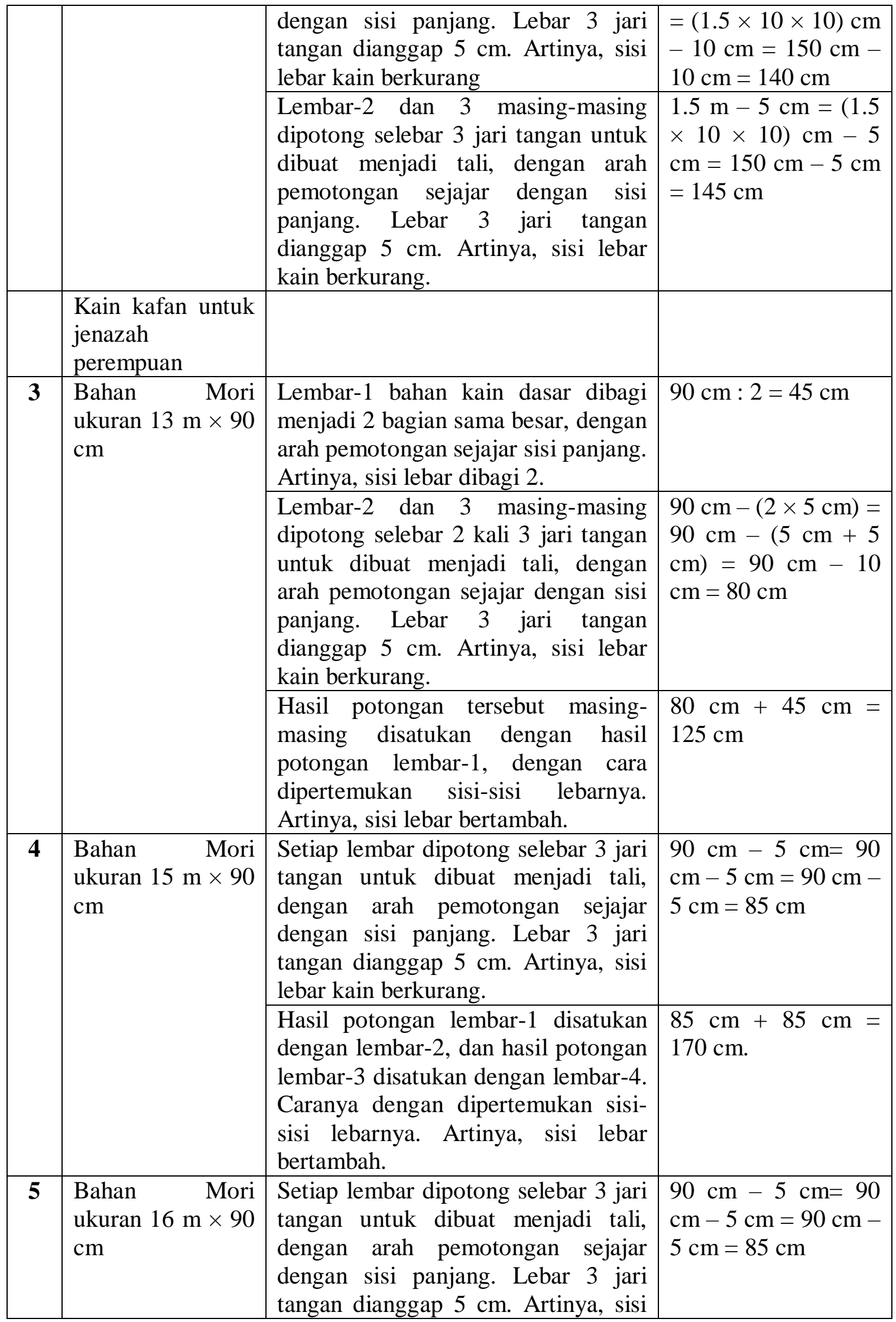


Vol 2 No 2 Desember 2021

Jurnal AlphaEuclidEdu

Received: 08/09/2021; Resived: 13/10/2021; Accepted: 30/12/2021

\begin{tabular}{|c|c|c|c|}
\hline & & lebar kain berkurang. & \\
\hline & & $\begin{array}{l}\text { Hasil potongan lembar-1 disatukan } \\
\text { dengan lembar-2, dan hasil potongan } \\
\text { lembar-3 disatukan dengan lembar-4. } \\
\text { Caranya dengan dipertemukan sisi- } \\
\text { sisi lebarnya. Artinya, sisi lebar } \\
\text { bertambah. }\end{array}$ & $\begin{array}{l}85 \mathrm{~cm}+85 \mathrm{~cm}= \\
170 \mathrm{~cm} .\end{array}$ \\
\hline
\end{tabular}

\section{Pembuatan 7 Utas Tali}

Tujuh utas tali dibuat dari hasil melipat dan memotong empat utas tali utuh sesuai bagian-bagian tali yang dibutuhkan untuk mengikat tubuh jenazah. Pembuatan 7 utas tali dijelaskan sebagai berikut.

Utasan-1 dibiarkan utuh, artinya melambangkan bilangan

Utasan-2 dipotong menjadi 2 bagian sama panjang, artinya melambangkan bilangan $\frac{1}{2}$ dan $\frac{1}{2}$.

Utasan-3 dipotong menjadi 2 bagian, bagian pertama sepanjang $\frac{3}{4}$ dari panjang utasan-3 dan bagian kedua sepanjang $\frac{1}{4}$ dari panjang utasan-3, artinya melambangkan bilangan $\frac{3}{4}$ dan $\frac{1}{4}$

Utasan-4 dipotong menjadi 2 bagian, bagian pertama sepanjang $\frac{3}{4}$ dari panjang utasan- 4 dan bagian kedua sepanjang $\frac{1}{4}$ dari panjang utasan-4, artinya melambangkan bilangan $\frac{3}{4}$ $\operatorname{dan} \frac{1}{4}$

Pembuatan 7 utas tali tersebut sesuai dengan konsep pembagian, lebih khususnya yaitu pembagian dengan pembagi bilangan dua. Dua bagian sama panjang diperoleh dengan membagi 1 dengan 2 . Untuk $\frac{3}{4}$ dan $\frac{1}{4}$, diperoleh dengan dua tahap, yaitu membagi 1 dengan 2, kemudian membagi hasil baginya dengan 2 .

Selain itu, rangkaian ini mengandung konsep operasi penjumlahan bilangan cacah dan pecahan pada jumlah panjang 7 utas tali sehingga terbukti benar ketujuhnya berasal dari 4 utas tali. Ketujuh bilangan tersebut jika dijumlahkan hasilnya adalah 4.

$$
\begin{aligned}
1+\frac{1}{2}+\frac{1}{2} & +\frac{3}{4}+\frac{1}{4}+\frac{3}{4}+\frac{1}{4}=\frac{4}{4}+\frac{2}{4}+\frac{2}{4}+\frac{3}{4}+\frac{1}{4}+\frac{3}{4}+\frac{1}{4} \\
& =\frac{(4+2+2+3+1+3+1)}{4} \\
& =\frac{16}{4} \\
& =4
\end{aligned}
$$

\section{Memandikan Jenazah}

\section{Banyaknya Proses Memandikan Jenazah}

Berdasarkan hadits riwayat Al-Bukhori dan Muslim, Rasulullah bersabda:

"Mandikan dia sebanyak tiga kali atau lima kali atau tujuh kali atau lebih banyak dari itu, jika kalian memandangnya perlu, dengan air dan daun bidara." Ummu "Athiyah bertanya, "Dalam bilangan ganjil?" Beliau menjawab, "Iya! Dan 
Vol 2 No 2 Desember 2021

Jurnal AlphaEuclidEdu

Received: 08/09/2021; Resived: 13/10/2021; Accepted: 30/12/2021

campurkanlah airnya dengan tumbuhan kafur (kapur barus) atau sedikit darinya di akhir siraman!".

Dari hadits tersebut terdapat beberapa bilangan yang jika diurutkan menjadi: 3, 5, 7, sampai dengan tak dibatasi jumlah maksimalnya. Bilangan-bilangan tersebut membentuk konsep pola tertentu yang dikenal dengan sebutan barisan bilangan. Adapun barisan yang dibentuk adalah barisan bilangan ganjil lebih dari sama dengan 3 pada jumlah proses memandikan jenazah, yaitu $3,5,7, \ldots$.

\section{Banyaknya Proses Memandikan Jenazah Dengan Air Larutan Sabun Atau Daun Bidara}

Ketika jenazah sudah dimandikan dengan air larutan sabun atau daun bidara sebanyak 2 kali namun jenazah masih belum bersih, maka jenazah kembali dimandikan sebanyak 2 kali pemandian dengan air larutan sabun atau daun bidara sehingga jumlah total memandikan saat ini adalah 4 kali. Namun jika jenazah masih belum bersih, jenazah kembali dimandikan sebanyak 2 kali pemandian dengan air larutan sabun atau daun bidara sehingga jumlah total memandikan saat ini adalah 6 kali. Begitu seterusnya.

Hal ini sesuai dengan konsep barisan aritmatika. Karena, barisan bilangan yang terbentuk suku-sukunya berurutan, dan setiap bilangan memiliki nilai selisih atau nilai beda yang tetap.

Jumlah proses memandikan jenazah dengan air larutan sabun atau daun bidara dilakukan sebanyak 2, 4, 6, .., n kali pada setiap dua kali pemandian. Artinya, ketika dua pemandian pertama, jenazah dimandikan dengan air larutan sabun atau daun bidara sebanyak dua kali. Ketika dua pemandian kedua jenazah dimandikan dengan air larutan sabun atau daun bidara sebanyak empat kali, Ketika dua pemandian ketiga jenazah dimandikan dengan air larutan sabun atau daun bidara sebanyak enam kali. Dan seterusnya.

Jumlah pemandian dengan air larutan sabun atau daun bidara pada setiap dua pemandian ke-n yaitu:

$$
\begin{gathered}
\mathrm{U}_{1}=a \\
\mathrm{U}_{2}=a+b \\
\mathrm{U}_{3}=a+2 b \\
\mathrm{U}_{\mathrm{n}}=a+(n-1) b
\end{gathered}
$$

\section{Waktu Untuk Memandikan Jenazah Dengan Air Larutan Kamper}

Berdasarkan hadits riwayat Al-Bukhori dan Muslim, Rasulullah bersabda: "Mandikan dia sebanyak tiga kali atau lima kali atau tujuh kali atau lebih banyak dari itu, jika kalian memandangnya perlu, dengan air dan daun bidara."

Ummu 'Athiyah bertanya, "Dalam bilangan ganjil?" Beliau menjawab, "Iya! Dan campurkanlah airnya dengan tumbuhan kafur (kapur barus) atau sedikit darinya di akhir siraman!'”.

Dan berdasarkan (Al Jaziri, 2017) bahwa di akhir pemandian, jenazah dimandikan dengan air larutan kamper atau wewangian lainnya. Dari dua hal di atas, maka pemandian dengan air larutan kamper dilakukan satu kali pada pemandian yang terakhir. Yaitu pada pemandian ke-3, ke-5, ke-7, dan seterusnya. Hal ini sesuai dengan konsep barisan bilangan. Adapun barisan yang dibentuk adalah barisan bilangan ganjil lebih dari sama dengan 3 , yaitu: $3,5,7, \ldots$. 
Vol 2 No 2 Desember 2021

Jurnal AlphaEuclidEdu

Received: 08/09/2021; Resived: 13/10/2021; Accepted: 30/12/2021

\section{Mengafani Jenazah}

\section{Banyaknya Lapisan Kain Kafan Pada Jenazah}

Berdasarkan Al-Jaziri (2019: 664-665), jenazah laki-laki dikafankan dengan tiga lapis kain. Sedangkan jenazah perempuan dikafankan dengan 5 lapis kain. Menurut Vera (2020) tiga lapis kain pada jenazah laki-laki itu terdiri dari 3 lembar kain dasar. Sedangkan pada jenazah perempuan, 5 lapis kain terdiri dari 2 lembar kain dasar, 1 lembar kain jilbab, 1 lembar kain jubah, dan 1 lembar kain sarung.

Banyaknya lapisan kain kafan pada jenazah mengandung konsep operasi penjumlahan sebagai berikut.

Tabel 8. Konsep Operasi Penjumlahan Bilangan Cacah Pada Banyaknya Lapisan Kain Kafan Pada Jenazah

\begin{tabular}{|l|l|c|}
\hline No & \multicolumn{1}{|c|}{$\begin{array}{c}\text { Banyaknya Lapisan Kain Kafan Pada } \\
\text { Jenazah }\end{array}$} & \multicolumn{1}{|c|}{$\begin{array}{c}\text { Penjumlahan Bilangan } \\
\text { Cacah }\end{array}$} \\
\hline $\mathbf{1}$ & $\begin{array}{l}\text { Jenazah laki-laki dikafani dengan 3 lapis } \\
\text { kain kafan }\end{array}$ & $1+1+1=3$ \\
\hline $\mathbf{2}$ & $\begin{array}{l}\text { Jenazah perempuan dikafani dengan 5 lapis } \\
\text { kain kafan }\end{array}$ & $2+1+1+1=5$ \\
\hline
\end{tabular}

\section{Menshalatkan Jenazah}

\section{Jumlah Minimal dan Maksimal Jama'ah Shalat Jenazah}

Dalam kasus umum, jumlah minimal jama'ah atau orang yang shalat jenazah di belakang imam adalah 3 orang. Adapun jumlah maksimal jama'ah adalah tidak dibatasi.

Hal ini sesuai dengan konsep pertidaksamaan linear satu variabel $\mathrm{x} \geq 3$, yaitu apabila akan dilaksanakan shalat jenazah, maka jumlah jama'ah yang harus hadir adalah minimal 3 orang, dengan x dimisalkan sebagai jumlah jama'ah.

Selain itu, konsep matematika yang terkandung di dalamnya adalah himpunan, yaitu himpunan jama'ah yang hadir untuk melaksanakan shalat jenazah. Ini sejalan dengan himpunan bilangan asli yang lebih atau sama dengan 3. Misalkan $\mathrm{H}$ adalah himpunannya, maka $H=\{x \mid x \geq 3, x$ adalah bilangan cacah $\}=\{3,4,5,6, \ldots\}$.

\section{Jumlah Barisan Jama'ah Shalat Jenazah}

Berdasarkan perkataan Nashiruddin Al-Albani, dalam shalat jenazah disunnahkan membuat tiga barisan atau lebih. Perkataan beliau ini sesuai dengan hadits riwayat AthThabrani, dari Abu Umamah ia berkata,

"Rasulullah pernah menshalatkan jenazah bersama tujuh orang jama'ah. Beliau menjadikan tiga orang dalam satu barisan (pertama), diikuti dua orang pada satu barisan (kedua), serta dua orang lain dalam satu barisan (ketiga)."

Hal ini sesuai dengan pertidaksamaan linear satu variabel $\mathrm{x} \geq 3$, yaitu apabila akan dilaksanakan shalat jenazah, jama'ah disunnahkan membentuk minimal tiga barisan atau lebih.

Selain itu, terdapat pula konsep himpunan, yaitu himpunan barisan jama'ah dalam shalat jenazah. Ini sejalan dengan himpunan bilangan asli yang lebih atau sama dengan 3. Misalkan $\mathrm{H}$ adalah himpunannya, maka $\mathrm{H}=\{\mathrm{x} \mid \mathrm{x} \geq 3$, $\mathrm{x}$ adalah bilangan cacah $\}=$ $\{3,4,5,6, \ldots\}$.

Hadits riwayat Ath-thabrani di atas kemudian dijelaskan alasannya mengapa 7 orang jama'ah dapat membentuk 3 barisan, dengan perkataan Al-Qadhi Ali bin 
Vol 2 No 2 Desember 2021

Jurnal AlphaEuclidEdu

Received: 08/09/2021; Resived: 13/10/2021; Accepted: 30/12/2021

Muhammad bin Ali Asy-Syaukai dalam kitab Nailul Authar, beliau berkata bahwa batas sebuah barisan disebut shaf adalah setiap barisnya minimal terdiri dari dua orang dan tidak ada batas maksimalnya.

Hal ini sesuai dengan konsep pertidaksamaan linear satu variabel $\mathrm{x} \geq 2$, yaitu apabila akan dilaksanakan shalat jenazah, jumlah jama'ah pada setiap barisan adalah minimal 2 orang.

Maka dalam kasus umum yaitu jumlah orang yang hadir untuk shalat jenazah adalah tidak kurang dari 6 orang, jumlah minimal barisan jama'ah shalat jenazah yang disunnahkan untuk dibentuk adalah tiga baris. Sedangkan jumlah maksimalnya adalah tidak dibatasi.

Hal ini sesuai pula dengan konsep pertidaksamaan linear satu variabel $\mathrm{x} \geq 6$, yaitu apabila akan dilaksanakan shalat jenazah, jama'ah dapat membentuk tiga barisan ketika jumlah jama'ah mencapai minimal 6 orang.

\section{Posisi Barisan Shalat Jenazah}

Posisi barisan jama'ah shalat jenazah mengandung konsep garis. Garis merupakan himpunan titik-titik yang berderetan. Pada shalat jenazah, jama'ah shalat berdiri saling berderetan dalam satu baris, hingga deretannya tersebut berhenti pada seseorang yang berdiri di kedua ujung barisan kanan dan kiri sesuai panjang barisan. Jika satu orang dalam barisan tersebut diibaratkan sebagai sebuah titik, maka semua orang dalam barisan terebut diibaratkan sebagai titik-titik yang berderetan hingga menjadi sebuah garis.

Ketika barisan pertama sudah dipenuhi dengan sejumlah orang, maka dibuatlah barisan kedua, ketiga, keempat, dan seterusnya di belakang barisan pertama. Dengan posisi setiap barisan sejajar dan tubuh jama'ah shalat menghadap ke kiblat dan jenazah. Hal ini sesuai dengan konsep garis sejajar, dimana barisan-barisan tersebut berjarak sama dalam satu bidang datar dan tidak pernah berpotongan meskipun diperpanjang sampai tak hingga.

\section{Jumlah Takbir Dalam Shalat Jenazah}

Takbir dilakukan secara berulang sebanyak 4 kali. Hal ini sesuai dengan konsep perkalian yang merupakan penjumlahan berulang. Misalkan perkalian a x b adalah penjumlahan bilangan $b$ sebanyak a kali, jadi

$$
\begin{gathered}
a \times b=b+b+b+\ldots+b \\
\text { Sebanyak a kali }
\end{gathered}
$$

Oleh karena itu, misal a adalah jumlah pengulangan takbir dalam shalat jenazah. Dan $b$ adalah jumlah takbir dalam 1 rakaat. Maka, perkalian bilangan cacah pada takbir shalat jenazah yaitu: $4 \underbrace{\times 1=1+1+1+1}=4$

\section{Posisi Berdiri Imam Terhadap Jenazah Laki-Laki dan Perempuan}

Dalam Al-Jaziri (2019) dijelaskan bahwa saat shalat jenazah, imam shalat berdiri di samping jenazah yang berbaring dengan posisi kepala jenazah di sisi utara dan kakinya di sisi selatan. Jika jenazah laki-laki, maka imam berdiri dengan posisi badan menghadap kiblat sekaligus ke arah sisi kepala jenazah. Dan jika jenazah perempuan, maka imam berdiri dengan posisi badan menghadap kiblat sekaligus ke arah sisi pinggul jenazah.

Pada posisi tersebut, mengandung konsep titik di luar garis. Jika dilihat dari atas, maka kedudukan jenazah yang berbaring dapat diibaratkan sebagai sebuah garis. Dan 
Vol 2 No 2 Desember 2021

Jurnal AlphaEuclidEdu

Received: 08/09/2021; Resived: 13/10/2021; Accepted: 30/12/2021

imam yang berdiri di sampingnya dapat diibaratkan sebagai sebuah titik. Sehingga tempat berdiri imam tidak menjadi bagian dari tempat berbaringnya jenazah, sebagaimana konsep titik di luar garis.

\section{Posisi Berdiri Seseorang Dalam Shalat Jenazah Terhadap Jenazah}

Pada saat berdiri, jika dilihat dari samping, maka posisi berdiri tegak tersebut menyerupai konsep ruas garis. Yaitu garis yang dibatasin oleh dua titik di kedua ujungnya. Termasuk di dalamnya terdapat pula konsep garis vertikal, yaitu garis yang tegak. Garis vertikal di sini adalah garis yang diilustrasikan dengan posisi berdiri seseorang di atas lantai yang melaksanakan shalat jenazah, dan posisinya tegak lurus dengan lantai tempat jenazah dibaringkan yang diilustrasikan sebagai garis horizontalnya. Artinya, jenazah yang berbaring dapat diibaratkan sebagai garis horizontal. Sebagaimana konsep garis tegak lurus, orang yang shalat dan jenazah dapat diibaratkan sebagai dua buah garis yang saling berpotongan tegak lurus.

Selain itu, orang yang berdiri dalam shalat jenazah, posisi tubuhnya membentuk sudut $180^{\circ}$. Dengan pinggang diibaratkan sebagai titik pangkal dari dua buah garis yang dibentuk. Kemudian bagian tubuh dari pinggang ke atas hingga kepala diibaratkan sebagai garis pertama, dan bagian tubuh dari pinggang ke bawah hingga ke kaki diibaratkan sebagai garis kedua. Karena ketika berdiri, posisi kepala dan kaki dianggap lurus dalam satu bidang, maka sudut yang terbentuk antara bagian tubuh atas dengan bagian tubuh atas dengan pinggang sebagai titik pangkalnya adalah $180^{\circ}$.

\section{Memakamkan Jenazah}

\section{Bentuk dan Ukuran Lubang Kubur}

Lubang kubur yang digali bentuknya menyerupai sebuah bangun ruang yaitu balok. Bentuk lubang tersebut memiliki ciri-ciri yang sama dengan balok, yaitu memiliki 6 buah sisi, yang berbentuk persegi panjang. Kemudian 3 pasang sisinya saling sejajar.

Adapun elemen-elemen pada balok yaitu sisi panjang, lebar dan tinggi juga terdapat pada lubang kubur. Sisi panjang pada lubang bersesuaian dengan tinggi badan jenazah, sisi lebar bersesuaian dengan lebar badan jenazah, dan sisi tinggi bersesuaian dengan kedalaman kuburan, yaitu setinggi berdirinya orang dewasa sambil mengangkat tangan ke atas.

\section{Simpulan dan Saran Simpulan}

Berdasarkan hasil penelitian yang dilakukan, dapat ditarik kesimpulan sesuai dengan jawaban dari rumusan masalah yaitu konsep matematika sekolah yang terdapat di dalam pemulasaraan jenazah adalah sebagai berikut: (1) Konsep Persegi panjang kelas I dan II SD; (2) Konsep Operasi hitung bilangan campuran kelas VI SD; (3) Konsep Operasi Penjumlahan kelas I, II, dan III SD; (4) Konsep Operasi pengurangan kelas I dan II SD; (5) Konsep Operasi perkalian kelas II dan V SD; (6) Konsep Operasi pembagian kelas II SD; (7) Konsep Barisan bilangan kelas VIII SMP; (8) Konsep Himpunan kelas VII SMP; (9) Konsep Pertidaksamaan Linear satu variabel kelas VII SMP; (10) Konsep Ruas garis kelas II SD; (11) Konsep Garis vertikal kelas II SD; (12) Konsep Garis horizontal kelas II SD; (13) Konsep Garis sejajar kelas IV SD; (14) Konsep Garis tegak lurus kelas IV SD; (15) Konsep Titik di luar garis kelas VII SMP; (16) Konsep Sudut $180^{\circ}$ kelas III SD; dan (17) Konsep balok kelas I dan II SD. 
Vol 2 No 2 Desember 2021

Jurnal AlphaEuclidEdu

Received: 08/09/2021; Resived: 13/10/2021; Accepted: 30/12/2021

\section{Saran}

Saran-saran yang dapat peneliti berikan setelah melakukan penelitian yaitu: (1) Kepada peneliti lain yang hendak meneruskan penelitian ini, hendaknya dapat memperbanyak buku referensi agar lebih banyak konsep matematika yang dapat digali; (2) Kepada guru yang mengambil manfaat dari penelitian ini, hendaknya dapat menyampaikan pentingnya pemulasaraan jenazah dengan metode dan situasi yang sesuai dengan kondisi kelas. Serta tidak lupa menyampaikan kepada siswa bahwa dalam pemulasaraan jenazah, terdapat konsep matematika seperti yang dipelajarinya di kelas.

\section{Referensi}

Al-Albani, Muhammad Nashiruddin. 2018. Fiqih Jenazah Menurut Al-Qur'an dan As-Sunnah. Jakarta: Pustaka Imam Syafi'i.

Al-Jaziri, Abdurrahman. 2019. Shalat dalam Fiqih 4 Mazhab. Jakarta: Noura Books.

Diah, Eka Kartiningrum. 2015. Panduan Menyusun Studi Literatur. Mojokerto: Lembaga Penelitian dan Pengabdian Masyarakat.

Fadhli Rabbani, Abu. 2017. Ahkamul Jana'iz Panduan Lengkap Mengurus Jenazah. Bogor: Media Tarbiyah.

Faishal bin Abdul Aziz Alu Mubarak. 2014. Riyadush Shalihin \& Penjelasannya. Jakarta: Ummul Qura.

Hobri.; Susanto.; Syaifuddin, Mohammad.; Maylistiyana, Dhika Elvira.; Hosnan.; Cahyanti, Anggraeny Endah.; Syahrinawati, Khoirotul Alfi. 2018. Senang Belajar Matematika Untuk SD/MI Kelas IV. Jakarta: Kemendikbud.

Mustofa, Amin.; Buchori.; Juliatun, Erna.; Hidayah, Isti. 2008. Senang Matematika Untuk SD/MI Kelas 2 Jilid 2. Jakarta: Depdiknas.

Permendikbud Nomor 21 Tahun 2016. Standar Isi Pendidikan Dasar dan Menengah. Jakarta: Lampiran Permendikbud nomor 21 tentang Muatan Matematika.

Pusfitasari, Eka. 2017. Eksplorasi Konsep Matematika Dalam Sistem Hukum Waris Islam Masyarakat Semudun. Skripsi. Untan Pontianak.

Sidiq, Umar.; Choiri, Moh Miftahul. 2019. Metode Penelitian Kualitatif Di Bidang Pendidikan. Ponorogo: CV. Nata Karya.

Soedjadi, R. 2000. Kiat Pendidikan Matematika Di Indonesia. Jakarta: Depdiknas.

Transyah, Eri Agus. 2018. Analisis Contoh Kontekstual Konsep Matematika Sekolah Yang Terdapat Dalam Ibadah Shalat. Skripsi. Untan Pontianak. 